\title{
A FRAMEWORK FOR ENTERPRISE AGILITY AND THE ENABLING ROLE OF DIGITAL OPTIONS
}

\author{
Eric Overby \\ Emory University \\ Atlanta, Georgia U.S.A. \\ Anandhi Bharadwaj \\ Emory University \\ Atlanta, Georgia U.S.A. \\ V. Sambamurthy \\ Michigan State University \\ East Lansing, Michigan U.S.A.
}

\begin{abstract}
In turbulent environments, enterprise agility (i.e., the ability for firms to sense environmental change and respond appropriately) is an important determinant offirm success. We present a framework for enterprise agility, identify the underlying capabilities that support enterprise agility, and explicate the enabling role of information technology and digital options.
\end{abstract}

Keywords Agility, enterprise agility, strategic agility, business agility, digital options, information technology

\section{INTRODUCTION}

As strategic and operating conditions become increasingly turbulent due to factors such as hyper-competition, increasing demands from customers, regulatory changes, and technological advancements, the ability to sense relevant change and respond appropriately becomes an important determinant of firm success. The term agile is commonly used to describe firms that are able to thrive in rapidly changing environments (Dove 200 i: Sambamurthy et al. 2003; Weill et al. 2002). Agility builds upon other concepts in management theory that pertain to firm success in turbulent 
environments, including dynamic capabilities (Teece et al. 1997), strategic flexibility (Ansoff 1980; Hitt et al. 1998), and market orientation (Kohli and Jaworski 1990; Narver and Slater 1990).

Enterprise agility is commonly broken down into two components: sensing and response. We develop a framework for the different combinations of sensing and response capabilities that firms may have, exploring the underlying capabilities (and deficiencies) that affect enterprise agility. The paper provides a conceptual schema and suggests normative insight for firms seeking to improve their enterprise agility. We also discuss how firm investments in information technology enable enterprise agility. Drawing on prior work in digital options (Sambamurthy et al. 2003), we explain how IT enables both the sensing and response components of agility by extending the reach and richness of firm knowledge and processes.

\section{BACKGROUND}

We define enterprise agility ${ }^{\mathrm{l}}$ as the ability of firms to sense environmental change and respond appropriately. The components of sense and respond are reflected in the various definitions of agility published in the academic literature, although some of the terminology differs. For example, Dove (2001) referred to the response component as "response ability," which he defined as the physical ability to act, and to the sensing component as "knowledge management," which he defined as the intellectual ability to find appropriate things to act on. Other terms in the definition also vary. For example, "environmental change" has been referred to as "market opportunities" (Sambamurthy et al. 2003), "continuous and unpredictable change" (Ward 1994), and "opportunities and threats" (Bessant et al. 2001). For purposes of breadth, we consider environmental change to encompass changes precipitated by competitors' actions, consumer preference changes, regulatory or legal changes, economic shifts, technological advancements, etc. Figure 1 illustrates how our definition corresponds to other published definitions.

In our context, an appropriate response is one that is supportive of a firm goal, such as to increase market share, capture new customers, or fend off competition. This adds in the element of strategy between sensing and response. The following quotes from a focus group comprised of six business school academics and two industry practitioners on the topic of enterprise agility illustrate this point:

You must have metrics associated with sensing and response. l.e, what are we sensing, why, and what decisions does it drive? Objectives will differ; you might want to shorten days of inventory, cycle time, or time to market. So it's not just sense and respond, but sense and appropriately respond. To judge appropriateness, the response must be measured against some goal.

${ }^{1}$ References to agility in this paper will relate to agility at the enterprise level. We consider enterprise agility, business agility, and organizational agility to be synonymous for purposes of this paper. 
Definition of Enterprise Agility

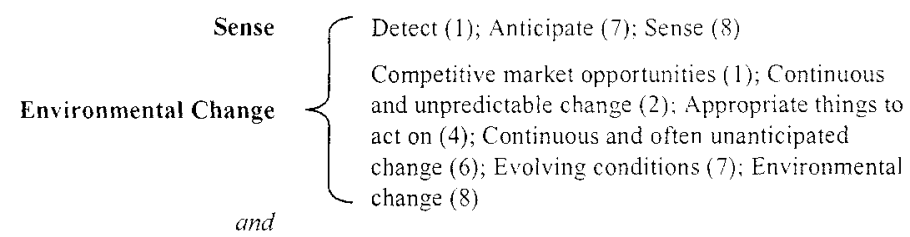

\section{Components of Other Definitions}

Seize ... with speed and surprise (1); thrive (2); intelligently, rapidly and proactively seizing opportunities and reacting to threats $(3)$; readily implement (5); fast response to ... seize the day (7); respond efficiently and effectively (8)

\footnotetext{
Citation in which agility is defined:

1. Sambamurthy et al. 2003

5. Weill et al. 2002

2. Ward, 1994

6. Sarkis 2001

3. Bessant et al. 2001

4. Dove 2001

7. Prewitt 2004

8. Ambrose and Morello 2004
}

Figure 1. Relationship of the Definition of Enterprise Agility to Other Definitions of Agility

An analogy is the squirrel in the road. The pending environmental change that the squirrel senses is that there's a car coming down the road. The squirrel responds by running back and forth, but its response is not appropriate because it gets run over.

Relative cost and quality also factor into the appropriateness of a response. For example, a response that is prohibitively expensive would not be appropriate; neither would a response of inadequate quality (Dove 2001). Another dimension of appropriateness is speed, which should be evaluated relative to the environmental change and will depend on such factors as whether the change was due to a competitor's move, a new technology, a regulatory change, etc. It will also vary by industry. For example, a quick response in one industry (e.g., aircraft manufacturing) may not be a quick response in another industry (e.g., mobile telephone manufacturing.) Consider the following quote from the focus group:

Agility will vary by industry. Consider the example of an elephant. Elephants are pretty agile for their environment. So speed is relative: responses might take years but still be agile.

Several aspects of the concept of enterprise agility are closely related to other concepts in management theory, many of which have informed our theorizing. We 
discuss three of these concepts: dynamic capabilities (Teece et al. 1997), market orientation (Kohli and Jaworski 1990; Narver and Slater 1990), and strategic flexibility (Aaker and Mascarenhas 1984; Ansoff 1980; Grewal and Tansuhaj 2001) and describe how they inform, yet are distinct from, enterprise agility.

Dynamic capabilities are a firm's ability to integrate, build, and reconfigure internal and external competencies to address rapidly changing environments (Teece et al. 1997). A basic tenet is that firms must continuously adapt their capabilities in order to maintain competitiveness (and perhaps competitive advantage.) Although the concept of dynamic capabilities shares many of the same concepts with enterprise agility-particularly its relevance to rapidly changing environments-dynamic capabilities is a much broader concept. Dynamic capabilities is relevant to all types of firm processes, whereas enterprise agility includes only those processes relevant for sensing environmental change and responding appropriately. In a sense, enterprise agility can be thought of as being enabled by a specific subset of dynamic capabilities.

The market orientation of a firm is reflected in the organization-wide generation of market intelligence pertaining to current and future customer needs, dissemination of the intelligence across departments, and organization-wide responsiveness to it (Jaworski and Kohli 1993; Kohli and Jaworski 1990). Market intelligence includes information about customers, competitors, and other factors such as technology and regulatory developments. As such, the market orientation concept includes all of the drivers of environmental change encompassed in the definition of enterprise agility. Similarly, both concepts explicitly include responsiveness to market intelligence and environmental change. However, there are slight differences between the two concepts. First, market orientation is an over-arching management philosophy or orientation. Enterprise agility, on the other hand, is better conceptualized as a set of capabilities and does not rise to the level of an overall orientation. Second, market orientation is heavily rooted in information processing: information is gathered, disseminated across departments, and acted upon. Conversely, enterprise agility is not necessarily as reliant on information processing. For example, it is possible for firms to act with agility without disseminating information across departments. In fact, disseminating information across departments may actually delay response and make firms less agile. Last, market oriented firms are largely focused on customer needs, ${ }^{2}$ and excessive focus on the customer can cause a firm to miss environmental change caused by other factors, such as that created by new technologies (Christensen and Bower 1996). Because enterprise agility is not as tightly coupled with customer needs analysis, agile firms may be less likely to fall into this customer focus trap.

Definitions of strategic flexibility include "the capability of a firm to proact or respond quickly to changing competitive conditions and thereby develop and/or maintain competitive advantage" (Hitt et al. 1998) and "the organizational ability to manage economic and political risks by promptly responding in a proactive or reactive manner to market threats and opportunities" (Grewal and Tansuhaj 2001). Firms possessing strategic flexibility tend to have flexible resource pools and diverse portfolios of strategic options, which allows them to practice effective "surprise management"

\footnotetext{
${ }^{2}$ Narver and Slater's (1990) definition of market orientation explicitly includes customer orientation.
} 
(Ansoff 1980). A review of the definitions reveals that strategic flexibility and enterprise agility are quite similar, although there is one major distinction. By construction, strategic flexibility refers to strategic issues, i.e., those that affect the businesses that a firm is in and how it creates competitive advantage in those businesses (Porter 1987). Strategic issues are distinct from operational or tactical issues (Porter 1996). Enterprise agility applies to both strategic and operational issues. For example, firms may need to be agile to handle strategic issues such as those created by competitor moves or changing customer preferences. In addition, firms may also need to be agile to handle operational issues such as those created by new regulations. For example, consider a new federal law that increases firm liability for worker's compensation claims. Agile firms must be able to sense how this change affects their operations and implement any needed safety improvements in a timely manner. Thus, because firms can be agile in both strategic and operational issues, enterprise agility envelops and extends strategic flexibility.

In addition to applying to both strategic and operational moves, enterprise agility can also apply to both proactive and reactive moves (Dove 2001). Proactive moves are innovative and place firms in a leadership position, whereas reactive moves are necessary to retain viability and competitiveness. To illustrate, consider two competing firms, $\mathrm{A}$ and $\mathrm{B}$. Assume that firm $\mathrm{A}$ has sensed a pending technological and/or regulatory change such as the FDA's approval of sucralose sweetener (marketed as Splenda) and launched a new line of low-calorie foods. Firm B, which does not track regulatory and technological developments as closely as does Firm A, senses the change in market demand created by firm $\mathrm{A}$ and quickly responds to launch its own line of low-calorie foods made with sucralose. Note that both firms have sensed and responded to environmental change: firm $A$ has behaved proactively in the face of regulatory and technological change, while firm B has behaved reactively due to a competitor's move. Thus, both moves might be considered agile, depending on whether they meet the criterion of appropriate response. ${ }^{3}$

\section{FRAMEWORK FOR ENTERPRISE AGILITY}

We present a framework for the different combinations of sensing and response capabilities that firms may have. Our framework consists of a $2 \times 2$ matrix with sensing on the $x$-axis and response on the $y$-axis and is shown in Figure 2. Agile firms are positioned in the upper-right quadrant (quadrant I), as they possess strong sensing and response capabilities. Firms with weak sensing and response capabilities are positioned in the lower-left quadrant (quadrant IV). Firms that are strong in either sensing or response, but not both, are positioned in the lower-right quadrant (quadrant II) and upper-left quadrant (quadrant III), respectively.

${ }^{3}$ Using the terminology commonly used in the strategy literature, firm A could be considered a "first-mover" and firm B a "fast follower" (Kerin et al. 1992; Lieberman and Montgomery 1988; Makadok 1998). We suggest that order of market entry is not necessarily associated with agility, as both first movers and fast followers can be agile. 


\subsection{Quadrant I (High Sensing, High Response): Agile}

In order to explicate the characteristics of firms in quadrant $I$, we further decomposed our definition of agility to examine (1) the types of environmental change that firms must be able to sense and (2) the types of responses that firms can implement. A summary of this decomposition appears as Table 1 . From this we are able to construct a profile of an agile firm.

Recall that relevant forces of environmental change include competitors' actions, consumer preference changes, economic shifts, regulatory and legal changes, and technological advancements. Different firm capabilities may be required to sense each of these types of change. For example, a firm may need a strong market intelligence capability to track competitors' actions and consumer preference changes. This may involve monitoring competitors' new product offerings, pricing and promotion strategies, and distribution strategies, as well as researching consumer needs and wants. Market intelligence may also help a firm sense changes due to economic shifts such as a downturn in the overall economy or rising commodity prices. Similarly, a strong government relations and/or legal department may be required to sense impending regulatory and legal changes of relevance to a firm. For example, telecommunications firms must be able to sense regulatory changes that impact their ability to offer different services (local and long-distance, landline and mobile telephone service, Internet service, cable television service, etc.) and the prices they can charge in different markets. Last, strong research and development and information technology capabilities may be needed to sense technological advancements and the ways in which a firm might leverage them to gain advantage. ${ }^{4}$

The relative importance of each of these forces of change (and the corresponding firm capabilities needed to detect them) will vary across industries and across time. For example, technological advancements may be very important early in the life cycle of products in industries such as consumer electronics. However, as technology stabilizes, competitors' actions in the form of price reductions or product bundling may become the more salient driver of environmental change. Despite fluctuation in their relative importance, most (if not all) of these forces are likely to be relevant to contemporary firms. Thus, most firms will require some degree of expertise in each of the corresponding underlying capabilities (market intelligence, R\&D, IT, etc.).

After sensing environmental change, there are multiple responses that a firm can make: (1) embark on a new venture (complex move), (2) adjust an existing venture (simple move), and (3) take no action (Ferrier et al. 1999). In other words, the scope of responses can differ (Dove 2001). The first response classification, embark on a new venture, encompasses such responses as launching a new product, creating a new distribution channel, or targeting a new customer segment. For example, Apple's launch

${ }^{4}$ It is wortin noting that some of these capabilities (legal, research and development, IT. market intelligence gathering, etc.) might be shared between a firm and its partners, or outsourced altogether. An exploration of how outsourcing of selected capabilities might impact firms' overall sensing capability is beyond the scope of our research but may represent a fruitful area for future research. 


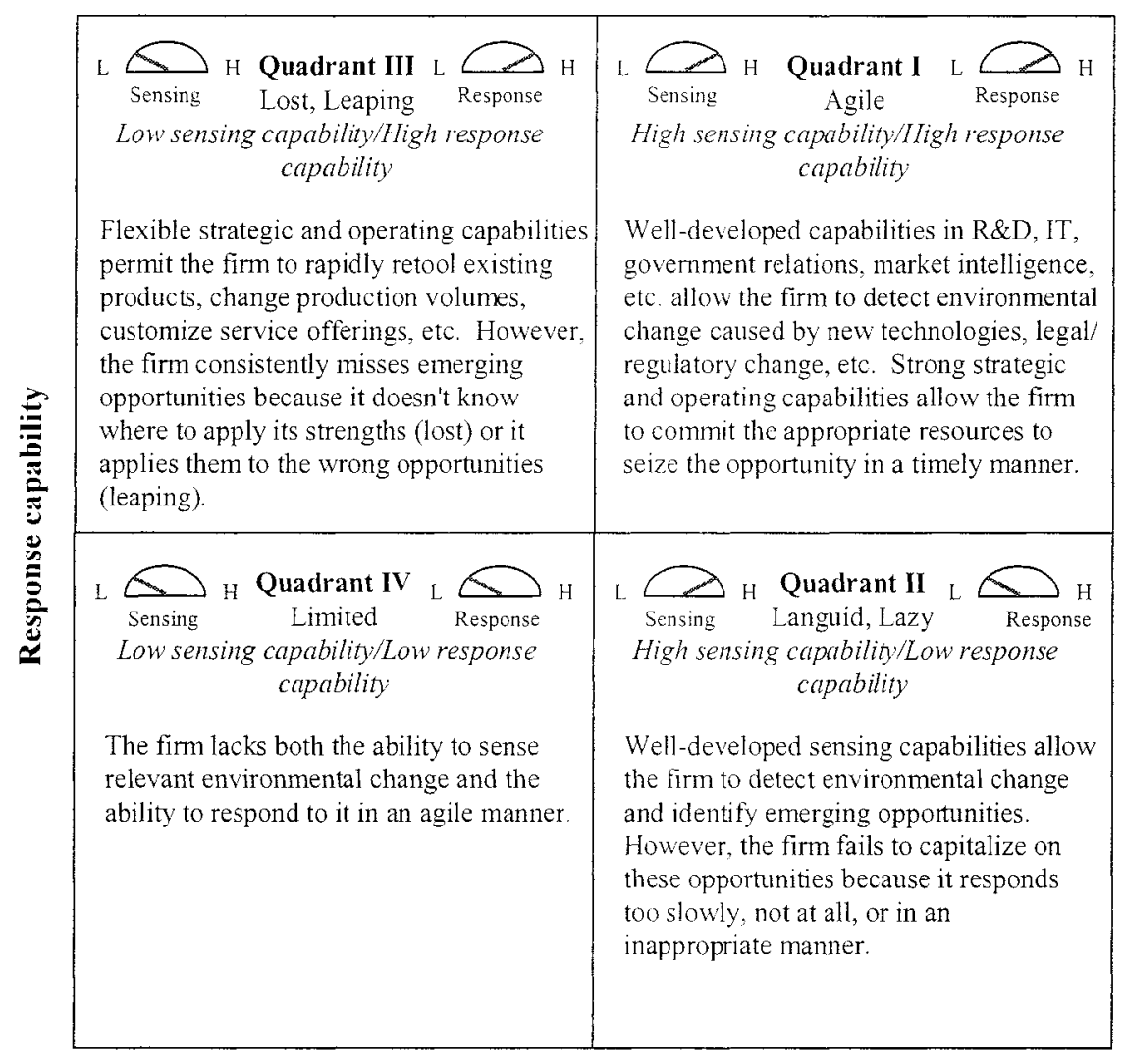

Sensing capability

Figure 2. Framework of Different Combinations of Sensing and Response Capabilities

of the iTunes music store in 2003 is an example of a firm responding to environmental change (technological advancements in music distribution) by embarking on a new venture (Apple Computer 2003). The second classification, adjust an existing venture, encompasses such responses as making a price change, increasing or decreasing production of an existing product, or adjusting product features. Responses in the second group can be thought of as incremental compared to responses in the first classification. For example, consider The New York Times Company's production of hundreds of thousands of extra copies of The Boston Globe (which it publishes) to sell to New England Patriots fans in Houston, TX, during the 2004 Super Bowl (Prewitt 2004). This is an example of a firm responding to a market opportunity (thousands of additional Globe readers in Houston, TX, for a few days) by adjusting an existing venture (the 
Houston-area production, distribution, and sale of the Globe.) The last classification, take no action, presents a paradox of sorts: can doing nothing be considered a response? We argue that the answer is yes. Recall that our definition of agility requires responses to be appropriate, which we measure in terms of conformance to firm goals. Because the most appropriate response for a firm may be to take no action, we argue that inactivity is a valid potential response.

A range of operating and strategic capabilities, including product development capabilities, systems development capabilities, supply chain and production capabilities, flexible resource utilization, and strategic decision making, are likely to be relevant to firm responses of all types. This is not meant to be an exhaustive list of relevant capabilities. Rather, it is illustrative of the types of capabilities that support a strong overall response capability.

For example, product development capabilities will facilitate a firm's ability to embark on new ventures such as launching new products and to adjust existing ventures such as adding product features (Clark and Fujimoto 1991). Systems development capabilities will affect how quickly and efficiently firms can implement IT-enabled offerings, be they hardware or software products for firms in technology industries or IT-enabled ventures (such as electronic commerce) for firms in other industries. Acxiom is an example of a firm that has invested in its systems development capabilities. Specifically, their use of iterative methodologies and modular, reusable code enables them to produce IT-based products rapidly to capitalize on emerging market opportunities (Levinson 2004). Because several of Acxiom's new products are IT-based, this example also applies to product development capabilities. Supply-chain and production capabilities may enable firms to adjust existing ventures by shifting production (upward or downward) to match a pending change in demand. For example, because of high supply chain visibility, firms such as DaimlerChrysler (Mayor 2004) and the United States Defense Logistics Agency (Overby 2004) are able to sense changes in supply and demand and scale their operations accordingly. Flexible resource utilization can allow firms to shift resources to areas of need, which will help them embark on new ventures and/or adjust existing ventures. For example, firms such as Merrill Lynch and the Guardian Life Insurance Company of America (Prewitt 2004) have flexible budgeting and staffing systems that permit them to reallocate resources to where they are most needed. A fifth item we include is strategic decision making capability. Not only must firms have enabling capabilities related to product development, supply chain, etc., but they must also have the ability to determine if a given response (be it complex, simple, or standing pat) is supportive of their strategic goals. In addition, they must be able to make this decision quickly to capitalize fully on the opportunity.

5This relates to the distinction between a firm being agile and actually displaying its agility. For example, consider two competing firms in the telecommunications industry, firms A and B, both of which have strong sensing and response capabilities. Further assume that a regulatory change permits both firms A and B to offer cable television service in certain markets. Although both firms sense the opportunity and have the available resources to seize it, only firm $B$ decides to do so. Firm A declines the opportunity because its strategy is to focus on its core competency of telephone service. Note that only firm B acts in an agile manner, although firm A could have. Thus, firm $\mathrm{A}$ is an agile firm, but it does not display its agility in this case. 
Table 1. Decomposition of Sensing and Response Capabilities

\begin{tabular}{|c|c|c|}
\hline & Relevant Types & $\begin{array}{c}\text { Selecting Enabling } \\
\text { Capabilities }\end{array}$ \\
\hline $\begin{array}{l}\text { Sensing } \\
\text { Environmental } \\
\text { Change }\end{array}$ & $\begin{array}{l}\text { - Competitors's actions } \\
\text { - Consumer preference changes } \\
\text { - Economic shifts } \\
\text { - Regulatory/legal changes } \\
\text { - Technological advancements }\end{array}$ & $\begin{array}{l}\text { - Market intelligence } \\
\text { - Government relations } \\
\text { - Legal } \\
\text { - Research and development } \\
\text { - Information technology }\end{array}$ \\
\hline $\begin{array}{l}\text { Appropriate } \\
\text { Response }\end{array}$ & $\begin{array}{l}\text { - Embark on new venture } \\
\text { (complex) } \\
\text { - Adjust existing venture } \\
\text { (simple) } \\
\text { - No action }\end{array}$ & $\begin{array}{l}\text { - Product development } \\
\text { - Systems development } \\
\text { - Supply chain } \\
\text { - Production } \\
\text { - Flexible resource } \\
\text { utilization } \\
\text { - Strategic decision-making }\end{array}$ \\
\hline
\end{tabular}

Returning to the framework, we can infer that firms in quadrant I have several characteristics, including strong sensing capabilities supported by $R \& D$, market intelligence, IT, legal, and government relations activities as well as strong response capabilities supported by strategic decision-making, product development, systems development, supply chain, and resource utilization skills.

An example of an agile firm is Wal-Mart. During a recent hurricane season in Florida, Wal-Mart was able to leverage its strong IT and data analysis capabilities to sense which disaster-related products were in the greatest demand, which included both predictable items such as flashlights and batteries and less predictable items such as beer and strawberry Pop-Tarts. Using its supply chain and distribution capabilities, WalMart was able to deliver additional disaster-related inventory to stores in affected areas to respond to this unusual spike in demand (Hays 2004).

\subsection{Quadrant II (High Sensing, Low Response): Languid, Lazy}

Firms in quadrant II (high sensing, low response) lack the response capabilities needed to seize emerging opportunities, although they are able to sense them. We characterize these firms as languid or lazy. Others have characterized such as firms as catatonic (Dove 2001). There are multiple potential reasons why firms might be able to sense environmental change relevant to their business but still fail to response to it in an agile manner, including those related to deficiencies in response-enabling capabilities such as product development, supply chain, or strategic decision-making. These deficiencies might be created by such factors as unnecessary bureaucracy, risk aversion, resource rigidity, poorly integrated processes, and/or agency problems. For example, unnecessary bureaucracy could slow down the strategic decision-making process, 
causing firms to miss emerging opportunities. This is related to the notion of "analysis paralysis," a condition in which a firm fails to make a timely decision because it is weighing too many possible options. Another possible reason, risk aversion, could cause firms to pass on an opportunity even when responding to it would be beneficial. Resource rigidity could prevent firms from being able to reallocate resources such as personnel, budget funds, or technology to areas of need. Poorly integrated processes may slow down product development and systems development, causing firms to miss opportunities. Last, agency problems may create incentives for managers to fail to act on opportunities that would be beneficial to the firm as a whole.

An example of a quadrant II firm was Xerox's Palo Alto Research Center (PARC) in the 1970s. Xerox engineers sensed impending changes in the computing industry and developed multiple innovations such as the graphical user interface, the mouse, and Ethernet. However, due to multiple issues, including conflicting strategies and issues with the U.S. Justice Department, Xerox did not market these innovations. Thus, although Xerox was able to sense changes in customer demand, it was unable to respond to it in a profitable manner (Alexander and Smith 1988).

\subsection{Quadrant III (Low Sensing, High Response): Lost, Leaping}

Firms in quadrant III (low sensing, high response) have strong response capabilities but are unable to sense the correct opportunities to pursue. We characterize these firms as lost or leaping. Others have characterized such as firms as spastic (Dove 2001). This lack of a sensing capability may be due to several factors, including skill deficiencies in such areas as market intelligence, $R \& D$, IT, legal, and government relations. These deficiencies might be created by such factors as over-reliance on outsourced providers, lack of integration, and competitive complacency. For example, lack of integration may hinder information flows within a firm, harming its overall sensing capability. Overreliance on outsourced providers may cause firm expertise in the outsourced area (be it IT, legal, R\&D, government relations, or market intelligence) to atrophy, making it difficult for firms to sense relevant environmental change. This is consistent with the theory of absorptive capacity (Cohen and Levinthal 1990), which suggests that firms must have a base of prior knowledge in an area in order to make sense of new developments in that area. Last, competitive complacency (Ferrier et al. 1999) may cause firms to become comfortable in their current strategic positions, causing them to ignore signals of change.

An example of a quadrant III firm is Cisco Systems circa 2001. Cisco has frequently received accolades for its supply chain capabilities which allow it to respond quickly to customer demand (McCormack et al. 2003; Poirier and Bauer 2001). However, Cisco failed to sense the downturn in the market for networking equipment in 2001 , leading to a $\$ 2.2$ billion inventory write-off in the third quarter of 2001 . Some commentators contend that Cisco's flexible response capabilities may have even exacerbated the situation by streamlining Cisco's ability to acquire inventory in order to respond to demand that never materialized (Berinato 2001). 


\subsection{Quadrant IV (Low Sensing, Low Response): Limited}

We characterize firms in quadrant IV (low sensing, low response) as limited. Not only do these firms lack the ability to sense environmental change, but they also lack response capabilities. The deficiencies presented for firms in quadrants II and III apply to firms in quadrant IV.

\section{INFORMATION TECHNOLOGY, DIGITAL OPTIONS AND AGILITY}

Information technology plays an important role in enabling the sense and response capabilities of firms (Bradley and Nolan 1998; Sambamurthy et al. 2003; Weill and Broadbent 1998). To the extent that environmental change is caused by advances in information technology or that appropriate responses depend on firms' IT competence, IT is directly related to enterprise agility. First, as discussed in the previous section, firms must have an adequate level of IT competence to be able to sense IT-based change relevant to their business. Consider that firms that sensed the opportunities created by emerging information technologies such as interactive HTML pages and the secure sockets layer (SSL) protocol were able to implement electronic commerce strategies before many of their competitors (Kalakota and Robinson 2001). Second, systems development capability is an important enabler of appropriate responses for firms in information technology-driven industries such as financial services, retailing, telecommunications, and hardware/software (Sambamurthy et al. 2003). Systems development capability is also important for firms in other industries. For example, many firms rely on information technology to support customer and supplier channels. The changing dynamics of customer and supplier relationships often require frequent modification and enhancement to supporting information systems (Lyytinen and Rose 2003). Third, IT may be indispensable for agility in contemporary environments (Haeckel 1999). This is because the volume of information that firms must process to sense relevant change has outstripped human capacity to process it. IT is required to augment human information processing so that managers can make sense out of what would otherwise overwhelm them. Similarly, responses in contemporary environments are often too complex for timely implementation without such IT support as communication infrastructure and automation. Haeckel and Nolan (1993) referred to managing in conditions so turbulent that sensemaking and action are impossible without IT as "managing by wire."

While the direct relationship between information technology and agility is important, the indirect relationship may be even more pronounced. Much of the business value of IT stems from its complementarities with business processes (Barua et al. 1995). Under this theory, IT contributes to performance in business processes such as product development, manufacturing, and supply chain, which in turn contribute to firm performance. Thus, other firm processes mediate the effect of IT on performance, although IT may also have direct effects on performance in certain circumstances. We submit that this is also the case for enterprise agility. 


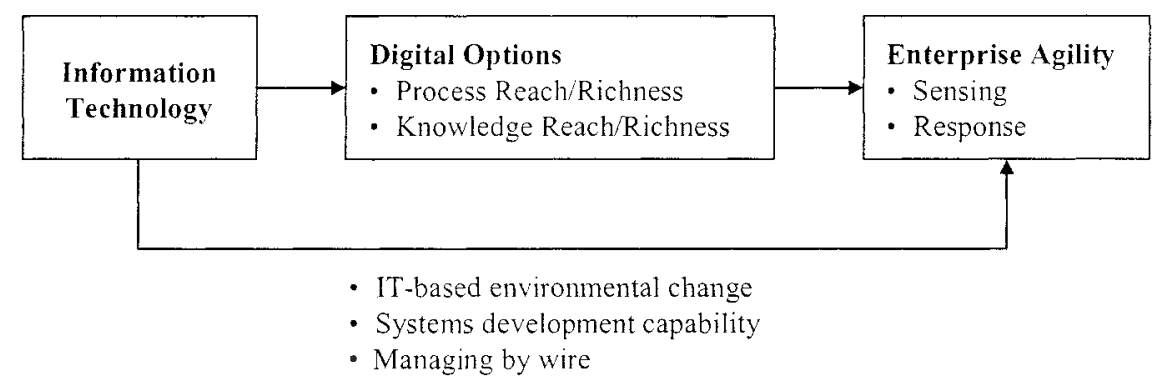

Figure 3. Relationship Between IT, Digital Options, and Enterprise Agility

Theory suggests that IT indirectly supports agility by providing firms with digital options, which are defined as a set of IT-enabled capabilities in the form of digitized work processes and knowledge systems (Sambamurthy et al. 2003). A basic premise of this theory is that IT enhances the reach and richness of a firm's knowledge and processes. Enhancements in the breadth of resources (reach) and quality of information (richness) available to a firm provide the firm with digital options. Digital options create a platform for enterprise agility by improving a firm's sensing capability and providing it with the knowledge and flexibility it needs to respond to opportunities created through environmental change. They are options in the sense that a firm may exercise them to apply to emerging opportunities, or they may remain unused, depending on a firm's environment and strategy (Fichman 2004; Trigeorgis 1996). The graphic in Figure 3 illustrates how IT provides firms with digital options and how these digital options enhance enterprise agility. Figure 3 also displays the direct relationship between IT and enterprise agility described above.

Digital options are created through enhancements to the reach and richness of firm knowledge and processes. Knowledge reach refers to the comprehensiveness and accessibility of codified knowledge that is available to a firm. Such knowledge may reside in internal databases, partner databases, or public databases. Well-architected IT systems can assist firms in accessing, synthesizing, and exploiting knowledge from a wide range of sources. Not only can IT extend knowledge reach, but it also enhances knowledge richness by providing firms with high-quality information that is timely, accurate, descriptive, and customized to the recipient. ${ }^{6}$ Information technologies such as decision support systems, data warehouses, and OLAP tools can help firms develop rich knowledge through real-time data monitoring, pattern recognition, and strategic scenario modeling (Wixom and Watson 2001). Knowledge reach and richness enhance firms' sensing capabilities by providing managers with high quality information about the state of the business, which helps them identify emerging opportunities and/or threats. For example, rich knowledge related to customer purchase behavior can help richness.

${ }^{6}$ We based some of these elements on Evans and Wurster's (2000) conceptualization of 
managers sense profitable new customer segments (Glazer 1991). Rich knowledge related to internal processes can help managers identify deficiencies such as fulfillment problems that are likely to be exposed as the competitive environment evolves. Also, the searching and filtering functionality of IT allows firms to monitor a wide range of data sources, providing firms with great reach to monitor developments related to new regulations, laws, technologies, and economic conditions. Knowledge reach and richness also support response capability by providing managers with the information they need to make strategic decisions in a timely manner. In addition, they support firms' response capabilities by providing managers with visibility to the resources (employees, equipment, budget, etc.) available to pursue emerging opportunities.

Similarly, IT creates digital options by extending process reach so that firms are better integrated internally and with external customers, suppliers, and partners. Infrastructural information technologies such as e-mail, voice mail, databases, intranets/ extranets, and groupware extend process reach, both within and external to a firm. Other information technologies such as supply chain systems, procurement systems, portals, transactional Web sites, and collaborative systems represent more specialized investments that extend process reach to external stakeholders. While process reach facilitates greater process participation among relevant internal and external stakeholders, process richness improves the quality of information available to process participants by making it more timely, accurate, relevant, and customized. Process reach and richness support firms' response capabilities by improving coordination internal and external to the firm, which enhances response-enabling capabilities such as product development, systems development, supply chain, production, and strategic decisionmaking. By supporting high-quality information exchange among numerous stakeholders, process reach and richness also enrich firms' opportunities to sense relevant environmental change.

Although individual information technologies can improve both a firm's knowledge and its processes, we submit that some technologies are more knowledge-oriented and others are more process-oriented. Further, we submit that knowledge-oriented IT is more directly supportive of a firm's sensing capability and that process-oriented IT is more directly supportive of a firm's response ability. To illustrate, data warehouses, data mining, OLAP, and other reporting tools are examples of knowledge-oriented information technologies, as these technologies help firms identify patterns within and extract knowledge from data. Because these technologies can help firms make sense out of apparent noise (Haeckel 1999), they directly support firms' sensing capability. Process-oriented IT systems are designed to help firms conduct business processes such as procurement, production, distribution, and billing. Examples of such systems include enterprise resource planning systems and supply chain systems. These technologies support firms' response capabilities by facilitating process integration and visibility, which in turn enables processes to be adjusted quickly in order to meet changing environmental conditions. Process-oriented systems often provide the raw data to knowledge-oriented systems such as data warehouses, although knowledge-oriented functionality such as reporting is often built directly into the process-oriented IT (e.g., a reporting module in an ERP system). 


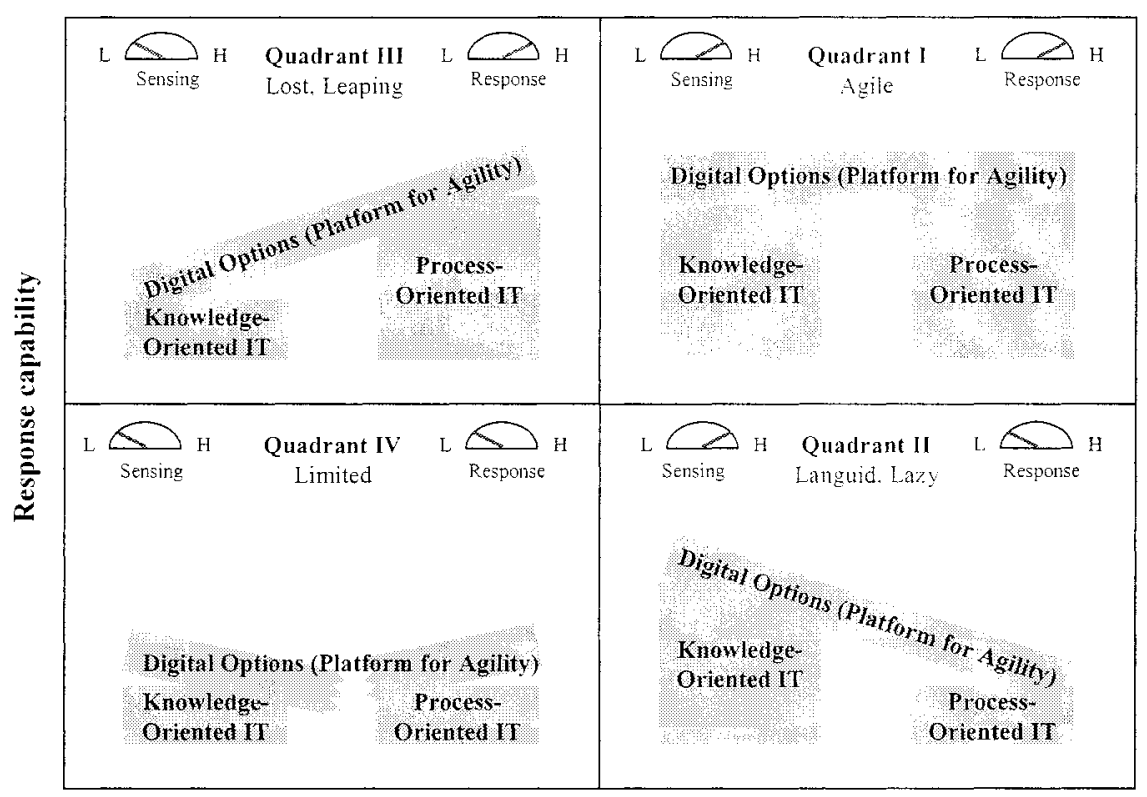

Sensing capability

Figure 4. Relationship Between Digital Options and the Enterprise Agility Framework

In terms of the framework, firms in quadrant III (low sensing, high response) may have sophisticated process-oriented IT but suboptimal knowledge-oriented IT. This is because strong process-oriented IT provides quadrant III firms with response capabilities, but deficiencies in knowledge-oriented IT may be one of the reasons why these firms fail to sense relevant environmental change. Similarly, firms in quadrant II (high sensing, low response) may have strong knowledge-oriented IT but poor processoriented IT. These firms may leverage knowledge-oriented IT to help them sense environmental change, but their lack of process-oriented IT hinders their ability to develop and implement responses, perhaps because they cannot reach the relevant stakeholders or communicate with them in a sufficiently rich manner. Deficiencies in either knowledge-oriented or process-oriented IT create an imbalance in the digital options platform, making it an unstable base from which to launch agile moves. On the other hand, knowledge-oriented and process-oriented IT may be a key reason why firms in quadrant I (high sensing, high response) have the sensing and response capabilities to be highly agile. They combine to provide firms with a stock of digital options that creates a solid platform from which to launch agile moves. Conversely, because firms in quadrant IV (low sensing, low response) lack both knowledge-oriented and processoriented IT, they are unable to accumulate a stock of digital options, hindering their overall agility. Figure 4 maps firms' knowledge-oriented and process-oriented IT capabilities to the enterprise agility framework and illustrates the concept of instability in the digital options platform. 


\subsection{How IT Might Hinder Enterprise Agility}

Depending on how it is deployed and managed, IT may actually hinder enterprise agility in certain circumstances. For example, monolithic IT architectures may hinder agility by limiting the range of strategic responses available to a firm. Such architectures may make it difficult for the firm to adjust processes to changing conditions, creating high costs when the firm seeks to pursue new strategies. Other systems may limit information visibility by storing data in ways that make it difficult to retrieve and/or interpret. Also, some systems may limit process reach by being incompatible with systems adopted by customers and suppliers. These issues, however, are not endemic to information technology in general, although some may be either reflective of early generations of information technology (e.g., monolithic, incompatible.) Rather, these issues stem from inappropriate investment in and/or management of information technology, just as issues may stem from inappropriate investment in and/or management of other firm resources such as human resources or manufacturing equipment. This calls attention to the importance of firm-level IT planning, implementation, and maintenance (Bharadwaj 2000; Weill and Broadbent 1998).

\section{CONCLUSION}

By juxtaposing firm sensing and response capabilities, our framework illustrates the enabling characteristics that support enterprise agility. We focused on the role of information technology, drawing upon digital options theory to show how IT supports agility by extending the reach and richness of firm knowledge and processes.

The framework helps to illustrate that both the sensing and response components must be present for a firm to be agile. For example, a firm that is highly effective at sensing environmental change but that is slow to act or acts inappropriately will not be agile. Similarly, a firm that is well positioned to respond appropriately will not be agile if it is unable to sense the correct opportunities to pursue. Thus, each of the components is a necessary, but not sufficient, condition for enterprise agility. However, the components are related, and they are likely to operate in a virtuous cycle. For example, a firm's ability to sense environmental change can greatly increase its likelihood of being able to develop appropriate responses by giving it a head start on its competitors. In turn, a strong response capability can provide incentives for a firm to look for emerging opportunities, thereby improving its sensing capability. Effective use of information technology is one method for firms to kick off and sustain this virtuous cycle, as IT enhances both sensing and response capabilities.

\section{REFERENCES}

Aaker, D. A., and Mascarenhas, B. "The Need for Strategic Flexibility," Journal of Business Strategy (5:2), 1984, pp. 74-82.

Alexander, R. C., and Smith, D. K. Fumbling the Future: How Xerox Invented, Then Ignored, the First Personal Computer, New York: W. Morrow, 1988. 
Ambrose, C., and Morello, D. I. "Designing the Agile Organization: Design Principles and Practices," Gartner, Inc., 2004, pp. 1-25.

Ansoff, H. I. "Strategic Issue Management," Strategic Management Journal (1 :2), 1980, pp. 132 148.

Apple Computer. "Apple Launches the iTunes Music Store," 2003 (available online at http://www apple.com/pr/library/2003/apr/28musicstore.html; accessed current October 13, 2004).

Barua, A., Kriebel, C. H., and Mukhopadhyay, T. "Information Technologies and Business Value: An Analytic and Empirical Investigation," Information Systems Research (6:1), 1995 , pp. 3-23.

Berinato, S. "What Went Wrong at Cisco," ClO Magazine, August 1, 2001, pp. 52-62.

Bessant, J., Francis, D., Meredith, S., Kaplinsky, R., and Brown, S. "Developing Manufacturing Agility in SMEs," International Journal of Technology Management (22:1/2/3), 2001, pp. $28-54$.

Bharadwaj, A. S. "A Resource-Based Perspective on Information Technology Capability and Firm Performance: An Empirical Investigation,"MIS Quarterly (24:1), 2000, pp. 169-196.

Bradley, S. P., and Nolan, R. L. Sense \& Respond: Capturing Value in the Network Era, Boston: Harvard Business School Press, 1998.

Christensen, C. M., and Bower, J. L. "Customer Power, Strategic Investment, and the Failure of Leading Firms," Strategic Management Journal (17:3), 1996,, pp. 197-218.

Clark, K., and Fujimoto, T. Product Development Performance: Strategy, Organization, and Management in the World Auto Industry, Boston: Harvard Business School Press, 1991.

Cohen, W. M., and Levinthal, D. A. "Absorptive Capacity: A New Perspective on Learning and Innovation," Administrative Science Quarterly (35), 1990, pp. 128-152.

Dove, R. Response Ability: The Language, Structure, and Culture of the Agile Enterprise, New York: John Wiley \& Sons, Inc., 2001.

Evans, P., and Wurster, T. S. Blown to Bits: How the New Economics of Information Transforms Strategy, Boston: Harvard Business School Press, 2000.

Ferrier, W. J., Smith, K. G., and Grimm, C. "The Role of Competitive Action in Market Share Erosion and Industry Dethronement: A Study of Industry Leaders and Challengers," Academy of Management Journal (42:4), 1999, pp. 372-388.

Fichman, R. G. "Real Options and IT Platform Adoption: Implications for Theory and Practice," Information Systems Research (15:2), 2004, pp. 132-154.

Glazer, R. "Marketing in an Information-Intensive Environment: Strategic Implications of Knowledge as an Asset," Journal of Marketing (55:4), 1991, pp. 1-19.

Grewal, R., and Tansuhaj, P. "Building Organizational Capabilities for Managing Economic Crisis: The Role of Market Orientation and Strategic Flexibility," Journal of Marketing (65:2), 2001, pp. 67-80.

Haeckel, S. H. Adaptive Enterprise: Creating and Leading Sense-and-Respond Organizations, Boston: Harvard Business School Press, 1999.

Haeckel, S. H., and Nolan, R. L. "Managing by Wire," Harvard Business Review (71:5), 1993 , pp. 122-132.

Hays, C. L. "What They Know About You," The New York Times, November 14, 2004, Section 3, p. 1 .

Hitt, M. A., Keats, B. W., and DeMarie, S. M. "Navigating in the New Competitive Landscape: Building Strategic Flexibility and Competitive Advantage in the 21st Century," Academy of Management Executive (12:4), 1998, pp. 22-42.

Jaworski, B. J., and Kohli, A. K. "Market Orientation: Antecedents and Consequences,"Journal of Marketing (57:3), 1993, pp. 53-70.

Kalakota, R., and Robinson, M. E-Business 2.0: Roadmap for Success, Boston: AddisonWesley, 2001. 
Kerin, R. A., Varadarajan, P. R., and Peterson, R. A. "First-Mover Advantage: A Synthesis, Conceptual Framework, and Research Propositions,"Joumal of Marketing (56:4), 1992,pp. $33-52$.

Kohli, A. K., and Jaworski, B. J. "Market Orientation: The Construct, Research, Propositions, and Managerial Implications," Journal of Marketing (54:2), 1990, pp. 1-18.

Levinson, M. "How to Build an Agile IT Department," CIO Magazine (17:21), August 15,2004, pp. 58-63.

Lieberman, M. B., and Montgomery, D. B. "First-Mover Advantages," Strategic Management Journal (9:Summer), Special Issue, 1998, pp. 41-58.

Lyytinen, K., and Rose, "The Disruptive Nature of Information Technology Innovations: The Case of Internet Computing in Systems Development Organizations," MIS Quarterly (27:4), 2003, pp. 557-595.

Makadok, R. "Can First-Mover and Early-Mover Advantages Be Sustained in an Industry with Low Barriers to Entry/Imitation?," Strategic Management Journal (19:7), 1998, pp. 683696.

Mayor, T. "The Supple Supply Chain," CIO Magazine (17:21), August 15, 2004, pp. 66-70.

McCormack, K. P., Johnson, W. C., and Walker, W. T. Supply Chain Networks and Business Process Orientation: Advanced Strategies and Best Practices, Boca Raton, FL: CRC Press, 2003.

Narver, J. C., and Slater, S. F. Slater "The Effect of a Market Orientation on Business Profitability," Joumal of Marketing (54:4), 1990, pp. 20-35.

Overby, S. "Inside an Agile Transformation," ClO Magazine (17:21), August 15, 2004, pp. 4854.

Poirier, C. C., and Bauer, M. J. E-Supply Chain: Using the Internet to Revolutionize Your Business, San Francisco: Berrett-Koehler Publishers, Inc., 2001.

Porter, M. E. "From Competitive Advantage to Corporate Strategy," Harvard Business Review (65:3), 1987, pp. 43-59

Porter, M. E. "What Is Strategy?," Harvard Business Review (74:6), 1996, pp. 61-78.

Prewitt, E. "The Agile 100," ClO Magazine (17:21), August 15, 2004, pp. 44-47.

Sambamurthy, V., Bharadwaj. A., and Grover, V. "Shaping Agility Through Digital Options: Reconceptualizing the Role of Information Technology in Contemporary Firms," MIS Quarterly (27:2), 2003, pp. 237-263.

Sarkis, J. "Benchmarking for Agility," Benchmarking (8:2), 2001, pp. 88-107.

Teece, D., Pisano. G., and Shuen, A. "Dynamic Capabilities and Strategic Management," Strategic Management Journal (18:7), 1997, pp. 509-533.

Trigeorgis, L. Real Options: Managerial Flexibility and Strategy in Resource Allocation, Cambridge, MA: MIT Press, 1996.

Ward, C. "What Is Agility?," Industrial Engineering (26:11), 1994, pp. 14-16.

Weill, P., and Broadbent, M. Leveraging the New Infrastructure: How Market Leaders Capitalize on Information Technology, Boston: Harvard Business School Press, 1998.

Weill, P., Subramani, M., and Broadbent, M. "Building IT Infrastructure for Strategic Agility," Sloan Management Review (44:1), 2002, pp. 57-65.

Wixom, B. H., and Watson, H. J. "An Empirical Investigation of the Factors Affecting Data Warehousing Success," MIS Quarterly (25:1), 2001, pp. 17-41.

\section{ABOUT THE AUTHORS}

Eric Overby is a doctoral student at the Goizueta Business School at Emory University. His area of specialization is information systems. Prior to pursuing an academic career, Eric was 
a senior manager in the consulting practices of BearingPoint, Inc. and Arthur Andersen LLP. He has worked with multiple Fortune 500 companies including The Coca-Cola Company, BellSouth, DuPont, Colgate-Palmolive, the Southem Company, and Georgia-Pacific, providing guidance in such areas as product development, legal and risk consulting, and IT and electronic commerce strategy, development, and implementation. His research explores patterns of activity in electronic markets and other virtual environments, and he is also interested in the business value of information technology. Eric can be reached at eric_overby@bus.emory.edu.

Anandhi Bharadwaj is an associate professor of Information Systems in the Goizueta Business School at Emory University. She received her Ph.D. from Texas A\&M University. Her research focuses on strategic and organizational issues related to information technologies and capabilities. Anandhi's research has been published in journals such as Management Science, MIS Quarterly, IEEE Transactions in Engineering Management, and Annals of Operations Research. She has served as an associate editor for MIS Quarterly and currently serves as an associate editor for Information Systems Research and on the editorial boatd of Journal of the AIS. Anandhi can be reached at ab@abus.emory.edu.

V. Sambamurthy (Ph.D., University of Minnesota, 1989) is the Eli Broad Professor of Information Technology at the Eli Broad Graduate School of Management at Michigan State University. $\mathrm{He}$ is also the Executive Director of the Center for Leadership of the Digital Enterprise, a new research center devoted to examining issues related to the interactions between business strategy, business process management, govemance, and information technology management. He has expertise in how firms successfully leverage information technologies in their business strategies, products, services, and organizational processes. Most of his work has been funded by the Financial Executives Research Foundation, the Advanced Practices Council (APC), and the National Science Foundation. His work has been published in journals such as MIS Quarterly, Information Systems Research, Management Science, Organization Science, Decision Sciences, and IEEE Transactions on Engineering Management. He has served on the editorial boards of a variety of journals, including MIS Quarterly, Management Science, Information Systems Research, Management Science, IEEE Transactions on Engineering Management, and Journal of Strategic Information Systems. Currently, he is the Editor-in-Chief of Information Systems Research. He can be reached at smurthy@msu.edu. 